\title{
APAKAH TINGKAT PENDIDIKAN KEPALA RUMAH TANGGA MEMPENGARUHI KESEJAHTERAAN RUMAH TANGGA?, STUDI KASUS DATA RUMAH TANGGA INDONESIA
}

\author{
Kukuh Arisetyawan, Universitas Brawijaya \\ pmpmpunesa@gmail.com \\ Sasongko, Universitas Brawijaya \\ sasongko0406@gmail.com \\ Rachmad Kresna Sakti, Universitas Brawijaya \\ kresnayangsakti@gmail.com
}

\begin{abstract}
ABSTRAK
Penelitian ini bertujuan untuk menganalisa pengaruh antara tingkat pendidikan kepala rumah tangga terhadap kesejahteraan rumah tangga di Indonesia. Model regresi logistic multinomial telah diperkirakan dengan peluang rumah tangga meraih kesejahteraan sebagai variabel dependen dan satu set tingkat pendidikan yang ditempuh semua rumah tangga sebagai variabel penjelas. Data diperoleh dari Indonesia Family Life Survey (IFLS) dengan penggunaan data longitudinal, IFLS 2000, 2007, dan 2014. Salah satu hasil utama adalah probabilitas rumah tangga meraih kesejahteraan lebih dapat diterima oleh rumah tangga dengan pendidikan SMA ke bawah. Resiko tidak sejahtera justru dimiliki oleh kepala rumah tangga yang berpendidikan SMA hingga perguruan tinggi. Hasil penting lainnya sesuai dengan analisa statistiknya adalah pengeluaran tertinggi terletak pada kepala rumah tangga berpendidikan SD dan yang ke dua ialah kepala rumah tangga berpendidikan SMA.
\end{abstract}

Kata Kunci: Pendidikan, Ekonomi, Rumah Tangga, Kesejahteraan.

\section{ABSTRACT}

This study aims to analyze the influence of the level of education of the head of the household on the welfare of households in Indonesia. The multinomial logistic regression model has been estimated with the opportunity for households to achieve well-being as the dependent variabel and a set of education levels taken by all households as explanatory variabels. Data were obtained from the Indonesia Family Life Survey (IFLS) with the use of longitudinal data, IFLS 2000, 2007, and 2014. One of the main results was the probability of households achieving welfare more acceptabel to households with lower secondary education. The risk of not being welfare is actually owned by the head of the household who has a high school education to college. Other important results according to the statistical analysis are the highest expenditure lies in the head of the household with elementary education and the second is the head of the household with a high school education.

Keywords: Education, Economics, Household, Welfare. 


\section{PENDAHULUAN}

Kegiatan ekonomi yang dilakukan meliputi tindakan konsumsi rumah tangga dan perolehan pendapatan untuk peningkatan kesejahteraan rumah tangga. Kesejahteraan sebuah rumah tangga perlu diukur untuk menentukan apakah rumah tangga tersebut berada dalam posisi sejahtera atau tidak. Sugiharto (2007) menerangkan bahwa indikator yang digunakan oleh Biro Pusat Statistik (BPS) untuk mengetahui tingkat kesejahteraan ada delapan, adalah (1) pendapatan, (2) konsumsi atau pengeluaran rumah tangga, (3) keadaan tempat tinggal, (4) fasilitas tempat tinggal, (5) kesehatan anggota keluarga, (6) kemudahan mendapatkan pelayanan kesehatan, (7) kemudahan memasukkan anak kejenjang pendidikan, dan (8) kemudahan mendapatkan fasilitas transportasi. Pernyataan diatas diperkuat dari Indeks Kesejahteraan Rakyat BPS (2016) dan The World Bank (2012) menjelaskan bahwa ukuran kesejahteraan rumah tangga diperlukan dari indikator moneter, indikator yang banyak digunakan adalah pendapatan dan pengeluaran.

Penelitian ini menggunakan proksi pengeluaran yang terdiri dari total pengeluaran untuk konsumsi pangan maupun non pangan dalam rumah tangga, hal ini dikarenakan tingkat kemiskinan dapat dilihat dari kondisi konsumsi rumah tangga dan menggambarkan kondisi taraf hidupnya (Rolleston 2011).Indikator pengeluaran yang dalam hal ini disebut juga konsumsi, dipilih karena sifatnya tetap dan relatif stabil terhadap berfluktuasinya pendapatan dari tahun ke tahun. Sejalan dengan hal tersebut, model mikro ekonomi Becker (1979) pada dasarnya menganggap rumah tangga sebagai dasarnya unit keputusan dalam organisasi ekonomi. Pengambilan keputusan rumah tangga dijadikan sebagai instrumen teori konsumen untuk memaksimalkan fungsi utilitas pada batasan anggaran tunggal yang diterapkan dalam rumah tangga (Bourguignon dan Chiappori, 2009).

Unit ekonomi yang paling menikmati dari proses kegiatan pengeluaran konsumsi adalah rumah tangga. Rumah tangga merupakan bagian unit kecil pada lingkup mikroekonomi yang merasakan manfaat dari kesejahteraan secara langsung. Oleh karena itu penelitian ini bertujuan untuk melihat kesejahteraan rumah tangga dengan berdasar pada karakteristik rumah tangga. Unit rumah tangga yang dimaksud disini dilihat dari karakteristik rumah tangga yang terdiri dari kepala rumah tangga, tingkat pendidikan, jenis kelamin, status perkawinan, dan jumlah anggota rumah tangga. Sehingga penelitian ini melihat kesejahteraan dari segi seberapa tinggi tingkat pendidikan, status perkawinannya, dan jenis kelamin kepala rumah tangganya (Rolleston 2011). Variabel-variabel yang terkait tersebut diperoleh dari data Indonesian Family Life Survery (IFLS) dengan tahun longitudinal 2000, 2007, dan 2012.

Penurunan tingkat kemiskinan dari rumah tangga merupakan cerminan dari kesejahteraan (Mulyo \& Widada, Arif Wahyu, 2015)(Bilenkisi, Fikret, Gungor, S, Mahmut, \& Tapsin, Gulcin, 2015). Selain itu Becker (1957) 
mengatakan bahwa kesejahteraan dapat dipengaruhi oleh tingginya tingkat pendidikan, jenis kelamin kepala rumah tangga, dan status perkawinan. Keterkaitan tersebutlah yang ingin dibahas dalam penelitian ini. Hipotesis yang sering muncul ketika tingkat pendidikan seseorang meningkat maka kesejahteraan meningkat. Namun, pada negara berkembang seperti Indonesia, kondisi pendidikan membuat adanya jurang ketimpangan. Hal ini memicu munculnya ketimpangan akses pendidikan (Todaro dan Smith, 2006). Lebih lanjut lagi Todaro dan Smith (2006), mengemukakan dua alasan mengapa pendidikan akan menciptakan ketimpangan. Pertama, terdapat biaya individual yang didapat dari keluarga miskin jauh lebih tinggi atau berat daripada biaya yang dikenakan pada rumah tangga yang kaya. Hal ini bisa terjadi karena biaya yang sama pada tingkat pendidikan yang sama, akan tetapi pendapatan dari kedua rumah tangga tersebut memiliki perbedaan dan akan terasa lebih berat keluarga yang tidak sejahtera. Kedua, mengenai manfaat yang akan diharapkan dari pendidikan dasar bagi rumah tangga miskin justru memperlihatkan lebih rendah. Artnya, biaya yang tinggi pada pendidikan hanya memberikan manfaat yang rendah bagi rumah tangga yang tidak sejahtera karena tingkat pengembalian investai akan terbatas. seseorang akan mendorong orang tersebut semakin produktif. Peningkatan produktifitas seseorang karena adanya peningkatan pengetahuan dan kemampuan serta cara berpikir, yang implikasinya adalah meningkatkan kesejahteraan. Wuryandari (2015) menyatakan apabila tingkat pendidikan rumah tangga semakin tinggi, maka akan mempengaruhi pola pengeluaran rata-rata rumah tangga yang ikut semakin naik juga. Peningkatan tersebut bisa pada pola pengeluaran pangan maupun pada pengeluaran non pangan. Persebaran tingkat pendidikan disemua jenjang dalam rumah tangga dapat dilihat pada Tabel 1.

Tabel 1. Kategori Tingkat Pendidikan

\begin{tabular}{|c|c|c|c|}
\hline Kategori Pendidikan & Freq & Percent & Cum. \\
\hline 1. Tidak Sekolah (0) & 2.256 & 6,58 & 6,58 \\
\hline 2. SD (1 - 6 Tahun) & 10.225 & 29,92 & 36,50 \\
\hline 3. SMP - SMA ( 7 - 12 Tahun) & 17.492 & 51,03 & 87,52 \\
\hline 4. Universitas & 4.277 & 12.48 & 100 \\
\hline
\end{tabular}

Sumber : IFLS 2000, 2007, 2014 (diolah, 2019)

Berdasakan tabel 1 diatas, Indonesia masih belum banyak orang atau rumah tangga yang pendidikannya hingga perguruan tinggi. Yang masih mendominasi adalah pendidikan SMP (Sekolah Menengah Pertama) dan SMA (Sekolah Menengah Atas) dengan prosentase 51,03\% serta SD (Sekolah Dasar) dengan prosentase 29,92\%. Hal ini dikarenakan tingkat pendidikan dapat menggambarkan kondisi taraf hidupnya (Rolleston 2011). Lebih lanjut lagi, Wuryandari (2015) dengan menggunakan data Susenas tahun 2011 mengatakan bahwa bahwa semakin tinggi tingkat pendidikan kepala rumah tangga, rata-rata pengeluaran juga akan semakin tinggi. Awan, Malik, Sarwar, 
dan Waqas (2011) juga mendukung pernyataan diatas dengan Hal ini sejalan dengan penelitian yang dilakukan oleh Awan, Malik, Sarwar dan Waqas (2011) bahwa lama pendidikan merupakan pengaruh yang kritis dari kemiskinan dan harus dibuat kebijakan yang tepat dalam mengatasi kemiskinan. Artinya, semakin meningkat lama pendidikan akan semakin menurun probabilitas menjadi miskin

Rumah tangga Indonesia masih bergelut dengan yang namanya urusan lapar (makanan). Indonesia dengan dasar data BPS masih mencatat bahwa penduduk Indonesia masih banyak pengeluaran yang digunakan untuk pangan daripada bukan pangan (pendidikan, rekreasi, tabungan, investasi) (BPS, 2018). Pengeluaran konsumsi rumah tangga dibedakan menjadi dua yaitu, pengeluaran non pangan dan pengeluaran pangan. Apabila pengukuran kesejahteraan menggunakan tingkat pengeluaran maka syarat dikatakan sejahtera jika, pengeluaran non pangan lebih besar dibandingkan dengan pengeluaran pangan. Hal ini sesuai dengan Mulyanto (2005) juga menjelaskan seperti halnya diatas, semakin kurang sejahtera apabila pengeluaran pangan semakin tinggi, sebaliknya apabila pengeluaran pangan semakin kecil maka semakin sejahtera rumah tangga tersebur. Berdasarkan data Indonesia Family Live Survey (IFLS), masih banyak rumah tangga yang belum sejahtera, seperti yang terlihat pada Tabel 2 .

Tabel 2. Jumlah Rumah Tangga yang Mengalokasikan Pengeluaran Pangan dan Non Pangan

\begin{tabular}{lcccc}
\hline \multicolumn{2}{c}{ Kelompok Barang } & $\begin{array}{c}\text { Bukan Kepala } \\
\text { Rumah Tangga }\end{array}$ & $\begin{array}{c}\text { Kepala Rumah } \\
\text { Tangga }\end{array}$ & Total \\
\hline $\begin{array}{l}\text { Pangan } \\
\text { Pangan } \\
\begin{array}{l}\text { Pangan } \\
\text { Pangan }\end{array}\end{array}$ & Non & 9.592 & 1.729 & 4.331 \\
\hline Total & 3.684 & 647 & 11.321 \\
\hline
\end{tabular}

Sumber : IFLS 2000, 2007, 2014 (diolah, 2019)

Hasil dari data yang dihimpun dari IFLS, rumah tangga yang ada di Indonesia dengan pengeluaran pangan lebih besar dari non pangan masih sebesar 1729 rumah tangga. Sedangkan untuk pengeluaran non pangan lebih besar dari pengeluaran pangan sebesar 647. Secara alamiah kuantitas pangan yang dibutuhkan seseorang akan mencapai titik maksimum sementara kebutuhan non pangan, tidak akan ada batasnya. Dengan demikian, besaran pendapatan yang dibelanjakan untuk pangan dari suatu rumah tangga dapat digunakan sebagai petunjuk tingkat kesejahteraan rumah tangga tersebut. Dengan kata lain, semakin tinggi pengeluaran untuk pangan, berarti semakin kurang sejahtera rumah tangga yang bersangkutan. Sebaliknya, semakin kecil pangsa pengeluaran pangan maka rumah tangga tersebut semakin sejahtera (Mulyanto, 2005). Sehingga perlunya peningkatan kesejahteraan tersebut dari perbaikan kualitas pendidikan sebagai dasar. Sesuai pernyataaan diatas, 
apabila pendidikan meningkat, maka kesejahteraan akan mengikuti meningkat. Pada kasus data IFLS ini akan dilihat peningkatan pendidikan apakah mempengaruhi kesejahteraan rumah tangga di Indonesa.

\section{METODE PENELITIAN}

Penelitian ini menggunakan pendekatan kuantitatif dengan teknik analisis statistik deskriptif dan inferensial serta menggunakan Multinomial Logistic Regression. Penelitian ini menitikberatkan pada pengujian hipotesis yang dilakukan untuk memahami substansi pengaruh tingkat pendidikan dalam meningkatkan kesejahteraan rumah tangga. Penelitian ini menggunakan data sekunder longitudinal yang berasal dari data Indonesia Family Live Survey (IFLS) atau di Indonesia dikenal dengan SAKERTI (Survei Aspek Kehidupan Rumah Tangga Indonesia) tahun 2000, 2007,dan 2014 bertujuan untuk mengestimasi jumlah penduduk dan indikator data mikro demografi. Dalam analisis empiris kami, kami menggunakan tahun dasar 2000 karena ini adalah tahun survei setelah terjadi krisis di mana informasi tentang responden dikumpulkan. Selain data utama dari IFLS, penelitian ini juga menggunakan data pendukung yang bersumber dari Badan Pusat Statistik (BPS), World Bank, dan sumber-sumber terkait yang berasal dari artikel, jurnal, dan literature lain yang relevan. Pengambilan data berdasarkan dari IFLS Buku 3A, Buku K (Konsumsi), dan PCE (Per Capita Expenditure).

Dalam penelitian ini populasi yang digunakan yaitu seluruh rumah tangga di Indonesia. Sedangkan sample yang digunakan dalam penelitian ini mengacu pada prosedur sampling yang digunakan pada IFLS-5 mewakili sekitar $83 \%$ penduduk Indonesia yang tinggal di 13 provinsi di Indonesia (RAND Corporation, 2016). Selanjutnya, penelitian ini sampel yang digunakan mencakup 15.904 rumah tangga yang diwawancarai dan sudah dapat mewakili seluruh rumah tangga di Indonesia. Kriteria sampel yang dipilih tersebut telah disesuaikan berdasarkan dengan kebutuhan penelitian.

Sesuai dengan uraian diatas maka pada penelitian ini untuk kategorisasi kesejahteraan akan menggunakan dasar dari World Bank (Effendi, 2015 ; dan World Bank, 2017), yaitu :

1. Jumlah proporsi total pengeluaran yang diterima oleh $40 \%$ lapisan bawah

2. Jumlah proporsi total pengeluaran yang diterima oleh $40 \%$ lapisan sedang

3. Jumlah proporsi total pengeluaran yang diterima oleh $20 \%$ lapisan atas.

Sedangkan untuk tingkat pendidikan memakai data IFLS dengan kategori SD, SMP, SMA, dan Perguruan Tinggi untuk dijadikan sebagai variabel independen. Oleh karena akan menggunakan tiga kategori pada variabel dependen maka digunakanlah multinomial logistic regression dengan menggunakan STATA 12.0. Sebelum melakukan estimasi maka ada beberapa langkah yang harus dilakukan, yakni, 1) melakukan uji asumsi 
multikolinearitas dengan Chi-kuadrat Pearson. Jika nilai $\mathrm{p}>\alpha$, maka antar peubah penjelas saling bebas (tidak terjadi multikolinearitas).

$$
\frac{\sum_{i} \sum_{j}\left(\left|n_{i j}-e_{i j}\right|\right)^{2}}{e_{i j}} \sim \chi_{(\mathrm{p})}^{2}
$$

Berikutnya adalah melakukan uji penduga parameter secara simultan. Hosmer dan Lemeshow (2000), pengujian koefisien tersebut secara simultan bertujuan untuk membandingkan nilai dari hasil pengamatan respon dengan penduga nilai respon untuk model penduh dan intersep.

$$
G=-2 \ln \left(\frac{L_{0}}{L_{1}}\right) \sim \chi_{(p)}^{2}
$$

Langkah ketiga adalah pengujian secara parsial dengan pembakuan pada penduga koefisien regresi yang mengikuti sebaran normal baku $(Z)$. berdasar pada uji Wald.

$$
W=\frac{\hat{\beta}_{l}}{S E\left(\hat{\beta}_{l}\right)} \sim Z
$$

Langkah terakhir adalah menguji kesesuaian model (Goodness of Fit). (Siegel (1992) mengatakan suatu ukuran yang digunakan untuk menjelaskan perbedaan antara frekuensi pengamtan dengan frekuensi harapan dinyatakan dengan statistik $X^{2}(v)$, dimana $\mathrm{v}=\mathrm{m}(\mathrm{k}-1)$-p. jika $X^{2}{ }_{(v)}=0$, maka frekuensi pengamatan akan sama dengan frekuensi harapan. Akan tetapi jika, $X^{2}{ }_{(v)}>0$ maka frekuensi pengamatan akan berbeda dengan frekuensi harapan.

\section{HASIL PENELITIAN DAN PEMBAHASAN}

Secara ringkas variabel dalam penelitian ini terdapat jenis kelamin kepala rumah tangga (X1), status perkawinan kepala rumah tangga (X2), dan tingkat pendidikan kepala rumah tangga (X3 : SD, X4 : SMP, X5 : SMA, X6: Universitas), yang variabel terebut merupakan variabel independen. Untuk pengkategorian tingkat pendidikan didasarkan pada tingkat pendidikan terakhir dalam kuesioner IFLS Buku 3A, yakni SD, SMP, SMA, dan Universitas. serta kategorikal pengeluaran konsumsi rumah tangga (Y) (Tidak Sejahtera, Cukup Sejahtera, dan Sejahtera) dapat dilihat pada Tabel 3.

Berdasarkan pada tabel 3 seluruh variabel akan dikategorikan sesuai dengan kebutuhan analisa dengan pengkategoriannya dari $0-1$ atau $1-3$. Pada kategorisasi pengeluaran diambil dengan cara menggunakan percentile 40 persen pengeluaran total bawah, 40 persen pengeluaran total menengah, dan 20 persen pengeluaran tinggi (world bank, 2017). Sehingga dapat disimpulkan apabila rumah tangga tersebut tidak sejahtera diberi kategorisasi 1, cukup sejahtera diberi kategorisasi 2, dan sejahtera diberi kategorisasi 3. Akhirnya akan dapat diketahui sebaran total pengeluaran kepala rumah tangga yang berada pada posisi kategorisasi tersebut. Dari data 15.904 rumah 
tangga ketika dikategorisasi berdasarkan kepala rumah tangga menjadi 2.603 kepala rumah tangga.

Tabel 3. Ringkasan Variabel

\begin{tabular}{llllcc}
\hline \multicolumn{1}{c}{ Variabel } & Obs. & Mean & Std. Dev. & Min & Max \\
\hline Head_SD & 12386 & .455595 & .4980444 & 0 & 1 \\
Head_SMP & 12386 & .1235266 & .3290539 & 0 & 1 \\
Head_SMA & 12386 & .1659939 & .3720901 & 0 & 1 \\
Head_Universitas & 12386 & .0629743 & .2429266 & 0 & 1 \\
& & & & & \\
Kat_Expenditure & 15735 & 1.786082 & .7413735 & 1 & 3 \\
Rumah Tangga & 15876 & .162639 & .3690381 & 0 & 1 \\
Jenis Kelamin & 14516 & .8224029 &. .3821864 & 0 & 1 \\
Status Perkawinan & 15875 & .7928949 & .4052442 & 0 & 1 \\
\hline
\end{tabular}

Sumber : IFLS (diolah, 2019)

Tabel 4. Kategorisasi Pengeluaran Total Rumah Tangga

\begin{tabular}{llll}
\hline \multicolumn{1}{c}{$\begin{array}{c}\text { Status Rumah } \\
\text { Tangga }\end{array}$} & \multicolumn{3}{c}{ Kategorisasi Pengeluaran Total } \\
\cline { 2 - 4 } $\begin{array}{l}\text { Kepala Rumah } \\
\text { Tangga }\end{array}$ & 1.123 & 1.026 & Sejahtera \\
\hline Sumber : IFLS (diolah, 2019) & & 482 \\
\hline
\end{tabular}

Sesuai dengan tabel diatas menandakan bahwa rumah tangga di Indonesia masih banyak pada taraf tidak sejahtera sebanyak 1.123 rumah tangga, rumah tangga yang cukup sejahtera sebanyak 1.026 rumah tangga dan rumah tangga yang sejahtera hanya sebanyak 482 rumah tangga. Ketika melihat klasifikasi pengeluaran rumah tangga dari tingkat pendidikan kepala rumah tangga dapat dihasilkan pada tabel 5.

Tabel 5. Klasifikasi Pengeluaran Rumah Tangga Berdasarkan Status Pendidikan Kepala Rumah Tangga

\begin{tabular}{lccccc}
\hline $\begin{array}{c}\text { Klasifikasi } \\
\text { Pengeluaran }\end{array}$ & SD & SMP & SMA & Diploma & Universitas \\
\hline 0 - Rp 1.879.333 & 146 & 70 & 95 & 7 & 39 \\
Rp 1.879.333 - & & & & & \\
Rp 2.791.084 & 155 & 73 & 94 & 15 & 51 \\
Rp 2.791.084- & & & & & \\
Rp 3.850.140 & 116 & 67 & 83 & 13 & 43 \\
Rp 3.850.140 - & & & & & \\
Rp 4.967.167 & 140 & 75 & 122 & 9 & 61 \\
> Rp 4.967.167 & 121 & 55 & 71 & 10 & 34 \\
\hline Sumber : IFLS (diolah, 2019) & & & &
\end{tabular}

Tabel diatas merupakan klasifikasi pengeluaran rumah tangga berdasarkan tingkat pendidikan. Dari data rumah tangga IFLS 15.904 ketika di analisa disesuaikan dengan ketersediaan data yang ada, jika data tidak 
lengkap maka secara langsung software STATA akan mengeliminasi sesuai perintah yang diberikan. Berdasarkan hal tersebut, paling mendomanasi pengeluaran tertinggi adalah kepala rumah tangga yang berpendidikan SMA ke bawah. Apabila melihat tabel tersebut bisa disimpulkan bahwa SMA ke bawah lebih sejahtera daripada kepala rumah tangga yang berpendidikan SMA ke atas. Hal ini nantinya akan dibuktikan secara statistik bagaimana pengaruh tingkat pendidikan terhadap kesejahteraan rumah tangga dengan proksi pengeluaran. Pengujian lanjutan untuk mengetahui tingkat pendidikan terhadap kesejahteraan rumah tangga maka akan diuji menggunakan multinomial logistic regression dengan bantuan STATA 12.0 yang hasilnya sebagai berikut.

Tabel 6. Hasil Marginal Effect Multinomial Logistic Regression

\begin{tabular}{lllllll}
\hline \multirow{2}{*}{$\begin{array}{c}\text { Variabel } \\
\text { Independen }\end{array}$} & \multicolumn{5}{c}{ Kesejahteraan Rumah Tangga } \\
\cline { 2 - 7 } & \multicolumn{2}{c}{ Tidak Sejahtera } & \multicolumn{2}{c}{ Cukup Sejahtera } & \multicolumn{2}{c}{ Sejahtera } \\
\cline { 2 - 7 } & M.E & p-value & M.E & p-value & M.E & p-value \\
\hline SD & 0.002 & 0.817 & 0.006 & 0.563 & -0.009 & 0.280 \\
SMP & -0.002 & 0.880 & 0.006 & 0.669 & -0.003 & 0.712 \\
SMA & 0.041 & 0.004 & -0.012 & 0.359 & -0.028 & 0.004 \\
PT & 0.032 & 0.046 & -0.005 & 0.712 & -0.026 & 0.018 \\
\hline
\end{tabular}

Sumber : IFLS (diolah, 2019)

Variabel yang dipilih pada tabel 3 hanya dua variabel yang tidak signifikan yakni jenis kelamin kepala rumah tangga dengan nilai pro $>$ chi $^{2}$ 0,82824 dan status perkawinan kepala rumah tangga pro $>\mathrm{chi}^{2} \quad 0,2410$ sehingga, tidak berpengaruh signifikan terhadap variabel dependen pengamatan. Oleh karena itu, variabel-variabel yang tidak signifikan tersebut akan dikeluarkan dari model agar memperoleh bentuk model yang lebih baik. Sedangkan untuk melihat pengaruh dari variabel independen terhadap dependen secara serentak akan dianalisi regresi multinomial logit menggunakan likelihood ratio test atau bisa disebut dengan Statistik G. diketahui dari hasil analisa bahwa hasil uji G untuk nilai dari LR $\mathrm{Chi}^{2}$ (30) sebesar 2360,68 dengan nilai p-value nya sebesar 0,000 < 0,05 yang dapat diartikan bahwa keseluruhan varibel independen tersebut serentak dapat menjelaskan variabel terikat pada taraf signifikansi $5 \%$.

Kelaikan suatu model dapat dilihat dengan menggunakan koefisien determinasi $\left(\mathrm{R}^{2}\right)$. Arti dari nilai koefisien tersebut dapat berbunyi besarnya proporsi variasi yang dimiliki dari variabel independen (X) dalam menjelaskan variabel dependennya (Y). Nilai dari Goodness of Fit tersebut beriksar antara 0 dan 1 atau $\left(0 \leq \mathrm{R}^{2} \leq 1\right)$. Dari hasil olah data dengan Stata, diperoleh hasil nilai Pseudo $\mathrm{R}^{2}$ sebesar 0.1275. Artinya, model regresi dikatakan layak.

\section{Tingkat Pendidikan Pengaruhnya Terhadap Kesejahteraan Rumah Tangga.}

Mengacu pada hasil analisa marginal effect pada multinomial logit 
didapat bahwa tingkat pendidikan kepala rumah tangga SD dan SMP pada ketiga kategori tidak signifikan karena nilai p-value $>0,05$ sesuai dengan yang ada di tabel 5. Sedangkan untuk tingkat pendidikan kepala rumah tangga SMA dan Universitas signifikan dengan nilai p-value $<0,05$. Dengan demikian yang menjadi kajian dari penelitian ini adalah tingkat pendidikan kepala rumah tangga menengah ke atas (SMA - Universitas).

Pada hasil analisa tersebut kepala rumah tangga yang berpendidikan SMA cenderung memiliki peluang untuk tidak sejahtera lebih besar dengan nilai marginal effect sebesar 0,041 . Artinya rumah tangga dengan pendidikan SMA memiliki peluang tidak sejahtera 4,1 persen lebih besar dibandingkan kepala rumah tangga dengan pendidikan SMA ke bawah. Kategori cukup sejahtera memiliki nilai marginal effect negative $(-0,041)$ dan tidak seginifikan $(0,359>0,05)$. Sedangkan, nilai marginal effect untuk kategori sejahtera memiliki nilai negatif dan signifkan sebesar -0,028, yang artinya kepala rumah tangga dengan pendidikan SMA memiliki peluang sejahtera lebih rendah 2,8 persen dibandingkan dengan kepala rumah tangga yang berpendidikan lain.

Hasil yang sama pula pada kepala rumah tangga yang berpendidikan di Universitas bahwa pada kategori tidak sejahtera memiliki nilai marginal effect yang positif dan signifikan sebesar 0,032. Artinya kepala rumah tangga yang berpendidikan tersebut memiliki kecenderungan untuk tidak sejahtera lebih besar 3,2 persen dibandingkan dengan yang lain. Berkebalikan dengan hal tersebut, pada kategori sejahtera nilai marginal effect nya negative dan signifikan sebesar -0,026. Artinya kepala rumah tangga yang memiliki pendidikan di Universitas mempunyai kecenderungan untuk sejahtera lebih rendah 2,6 persen dibandingkan dengan tingkat pendidikan yang lain.

Beberapa temuan diatas menandakan bahwa tingkat pendidikan kepala rumah tangga SMA keatas termasuk Universitas (Diploma dan Sarjana) mengalami peluang untuk meraih kesejahteraan rumah tangga yang rendah. Hal ini disebabkan karena lapangan kerja tidak siap menerima lulusan dengan berbagai macam tuntutan gaji dan dengan spesifikasi keahlian yang sesuai. Pratomo (2018) juga menguatkan bahwa variabel kepala rumah tangga dengan kependidikan SMA/SMK maupun lulusan perguruan tinggi memiliki koefisien negative yang artinya kepala rumah tangga memiliki tanggung jawab besar terhadap rumah tangganya untuk memaksakan harus tetap masuk dalam pasar kerja, apa pun jenis sektor pekerjaanya. Temuan ini sama hal nya dengan data dari BPS (Badan Pusat Statistik), yang menyatakan bahwa mayoritas yang berpendidikan SMA keatas sebagian besar mengalami peningkatan pengangguran 60 persen pada tahun 2014 dan 74 persen pada tahun 2018. Sebaliknya pengangguran yang berpendidikan SMA ke bawah prosentase menganggurnya turun dari 55 persen menjadi 10 persen.

Fenomena ini terjadi karena orang yang berpendidikan SMA ke bawah akan siap menerima apa saja pekerjaan yang ditawarkan dan dengan gaji berapa pun. Seharusya, tingkat pendidikan kepala rumah tangga dapat membuktikan bahwa kemiskinan akan berkurang dengan meningkatnya 
tingkat pendidikan kepala rumah tangga. Hasil penelitian ini sejalan dengan penelitian Akerele dan Adewuyi (2010) yang menyatakan bahwa kemiskinan lebih tinggi di antara kepala rumah tangga yang berpendidikan menengah ke atas. Pendapat tersebut juga sesuai dengan Bilenkisi, dkk (2015) bahwa kepala rumah tangga yang lulus pada tangkat SMA cenderung memiliki probabilitas meraih sejahtera lebih rendah. Bahkan Okojie (2002) menenkankan lebih spesifik lagi yakni rumah tangga yang dikepalai wanita dengan pendidikan menengah mencatat kemungkinan kemiskinan yang lebih tinggi dan kesejahteraan menurun. Akan tetapi hal ini sebenarnya tidak mengecilkan pentingnya sebuah pendidikand alam mengurangi tingkat kemiskinan. Ketika ada fenomena hasil penelitian seperti ini dan dari data BPS mendukung bahwa rumah tangga dengan pendidikan menengah keatas mengalami kecenderungan sejahtera lebih rendah haruslah mendapat perhatian khusus. Peran pembangunan kapasitas dan pengembangan sumber daya manusia dalam memberantas kemiskinan tidak bisa terlalu ditekankan. Pendidikan melengkapi orang-orang dengan informasi dan teknologi baru yang diperlukan untuk meningkatkan kegiatan ekonomi (Ruel et al., 1998; Oniang'o dan Makudi, 2002). Kebijakan yang akan memastikan keberlanjutan dan peningkatan akses ke pendidikan akan sejalan untuk mengurangi kemiskinan di wilayah studi.

\section{SIMPULAN}

Tujuan dari penelitian ini adalah untuk menguji status kesejahteraan rumah tangga berdasarkan karakteristik demografis di Indonesia, dalam hal tersebut studi ini menitikberatkan pada tingkat pendidikan kepala rumah tangga karena kepala rumah tangga dijadikan sebagai pengambil keputusan dalam keluarga. Penggunaan data IFLS ini sudah mewakil 85\% rumah tangga yang terdapat di Indonesia. Sekaligus ketika dibandingkan dengan data BPS akan relatif mendekati sama. Berdasarkan hasil tersebut dapat disimpulkan bahwa penggunaan data IFLS pada kondisi rumah tangga miskin dan tidak sejahtera peluangnya lebih besar kepada kepala rumah tangga yang berpendidikan SMA hingga perguruan tinggi. Hal ini dikarenakan individu yang berpendidikan menengah hingga atas memiliki harapan yang tinggi akan pekerjaan, gaji, dan status social. Berbeda dengan individu dalam rumah tangga yang berpendidikan menengah ke bawah, cenderung lebih sejahtera karena mereka bisa menerima pekerjaan dengan gaji berapa pun yang telah ditetapkan.

\section{DAFTAR RUJUKAN}

Akerele, D. and Adewuyi, S.A. 2010. Analysis of Poverty Profiles and Socioeconomic Determinants of Welfare among Urban Households of Ekiti State, Nigeria. Current Research Journal of Social Sciences 3(1): 1-7, 2011. ISSN: 2041-3246 
Becker, Gary S. (1957, 1971). The Economics of Discrimination. Chicago: The University of Chicago Press, 2nd edition.

B.Grusky (Ed.), Social Stratification: Class, Race and Gender in Sociological Perspective. Boulder: Westview Press, 365-83.

Bian, Yanjie. 1997. "Bringing Strong-ties Back In: Indirect Ties, Network Bridges, and Job Searches in China". American Sociological Review(64): 366-85.

Badan Pusat Statistik (BPS), 2016, Indeks Kesejahteraan Rakyat, Badan Pusat

Statistik,Jakarta.https://www.bps.go.id/publication/2016/11/23/f6d6e88 96c13653e09ae0862/indikator-kesejahteraan-rakyat-2016.html. diakses 05 Mei 2019

Bilenkisi, Fikret, Gungor, S, Mahmut, \& Tapsin, Gulcin. 2015. The Impact of Household Heads' Education Levels on the Poverty Risk: The Evidence from Turkey. Educational Sciences: Theory \& Practice. Vol. 15, no. 2, hh. 337-348.

Chavoshbashi, F., Ghadami, M., Broumand, Z., \&Marzban, F. (2012). Designing dynamic model for measuring the effects of cultural values on Iran's economic growth. African Journal of Business Management, 6(26), 7799-7815. https://doi.org/10.5897/AJBM11.2473.

David B. Grusky, (1994) Social Stratification: Race. Class and Gender in Sociological Perspective. Boulder: Westview Press, 260-64.

Gounder, R dan Xing, Z. 2012. Impact of Education and Health on Poverty Reduction : Monetary and Non Monetary Evidence from Fiji. Economic Modelling 29 (2012) 787-794.

Lind, Jo Thori. 2000. The Use of Household Welfare Functions to Estimate Equivalence Scales. Statistic Norway Research Departement. Page 166.

Moxon, D. (2011). Consumer culture and the 2011 "Riots". Sociological Research Online, 16(4), 1-5.

Mulyanto, 2005. Kemiskinan dan Kebutuhan Pokok. Rajawali. Jakarta 
Oniang'o, R. and E. Mukudi, 2002. Nutrition and Gender: A Foundation for Development. Brief 7 of 12, UN ACC/SCN, Geneva.

Pratomo, Devanto Shasta. 2017. Fenomena Pengangguran Terdidik di Indonesia. Sustainable Competitive Advantage-7 (SCA-7). FEB Unsoed. https://docplayer.info/70352042-Fenomena-pengangguranterdidik-di-indonesia.html. [10 Juni 2019.]

RAND Corporation. (2016). The Fifth Wave of the Indonesia Family Life. RAND LABOR AND POPULATION, Volume 1. Retrieved from RAND LABOR AND POPULATION: https://www.rand.org/labor/FLS/ IFLS/ifls5.html.

Rolleston, C. 2011. Educational access and poverty reduction: The case of Ghana 1991-2006. International Journal of Educational Development, $31,338-349$.

Ruel, M.T ., J.L. Garratt, S.S. Morris, D. Maxwell,A. Oshaug, P. Engle, P. M enon, A. Slack and L. Haddad, 1998. Urban challenges to foods and nutrition security: A review of food security health and care giving in cities. FCND Discussion paper no. 51. IFPRI.

Wuryandari, Ratna Dewi. 2011. Faktor-Faktor yang Mempengaruhi Pengeluaran Makanan, Pendidikan, dan Kesehatan Rumah Tangga Indonesia (Analisis Data Susenas 2011). Jurnal Kependudukan Indonesia | Vol. 10 No. 1 Juni 2015 | 27-42. 